\title{
KREATIVITAS SENI MELALUI METODE COLLECTIVE PAINTING
}

\author{
Tri Indah Hariyani ${ }^{1}$, Nur Fajrie. ${ }^{2}$, dan Mila Roysa ${ }^{3}$ \\ Pendidikan Guru Sekolah Dasar, Universitas Muria Kudus \\ Email: indahtrihariyani@gmail.com
}

\section{Info Artikel}

\section{Sejarah Artikel:}

Diserahkan: 2 Juni 2021

Direvisi: 23 Juni 2021

Disetujui: 28 Juni 2021

Keywords: Elaboration, Collaboration, Emotional.

\section{Abstract}

The application of the collective painting method can be used as variations and innovative methods to foster children's artistic creativity in expressing themselves. The characteristics of children in the village of Mayongkidul Jepara who like to learn while playing are in line with the implementation of the collective painting method. The purpose of this study was to analyze and describe the work process and the effect of applying the collective painting method. This type of research uses mixed methods with a Sequential Exploratory design. The stages of data analysis carried out are in the form of: presentation, transformation, correlation, consolidation, comparison and data conclusions through validity and reliability tests of the data including interviews, observation and documentation study. The results of this study indicate that there are 3 aspects of value, namely the value of elaboration, the value of collaboration and the emotional value of the effect of applying the collective painting method to foster artistic creativity in children in Mayongkidul Jepara Village so that the collective painting method can be used as an alternative in conveying learning arts and culture and skills.

\begin{abstract}
Abstrak
Penerapan metode collective painting bisa dijadikan variasi dan inovasi metode untuk menumbuhkan kreativitas seni anak dalam mengekspresikan diri. Karakteristik anak di desa Mayongkidul Jepara yang gemar belajar sambil bermain sejalan dengan pelaksanaan dari metode collective painting. Tujuan dari penelitian ini adalah untuk menganalisis dan mendeskripsikan proses berkarya serta pengaruh penerapan metode collective painting. Jenis penelitian ini menggunakan metode mixed methods dengan desain Sequential Exploratori. Adapun tahapan analisis data yang dilakukan yakni berupa penyajian, transformasi, korelasi, konsolidasi, perbandingan dan kesimpulan data melalui uji validitas dan uji reliabilitas dari data meliputi wawancara, observasi dan studi dokumentasi. Hasil dari penelitian ini menunjukkan adanya 3 aspek nilai yakni nilai elaborasi, nilai kolaborasi dan nilai emosional dari pengaruh penerapan metode collective painting untuk menumbuhkan kreativitas seni pada anak di Desa Mayongkidul Jepara sehingga metode collective painting dapat digunakan sebagai alternatif dalam menyampaikan pembelajaran seni budaya dan keterampilan.
\end{abstract}




\section{PENDAHULUAN}

Pendidikan seni pada anak tidak hanya dilihat dan dinilai dari hasilnya, namun juga harus memberikan makna dan pengalaman termasuk pengalaman estetik yang dapat diterima oleh anak selama proses berlangsung. Tujuan pendidikan seni rupa salah satunya adalah menumbuhkan potensi kreativitas anak. Menurut Fajrie (2016: 155) menyatakan bahwa pembelajaran seni rupa adalah kegiatan seni sebagai penanaman estetika yang dapat diserap oleh alat indrawi dan wujudnya terdiri dari unsur rupa berupa garis, bidang, ruang, bentuk, warna, gelap terang, dan tekstur. Sepadan dengan pendapat Sumanto (2006: 20) bahwa pendidikan seni rupa untuk anak usia sekolah dasar adalah upaya pemberian pengalaman dan pengetahuan dasar kegiatan kreatif pada seni rupa dengan menerapkan seni sebagai alat pendidikan.

Keterlibatan anak dalam mengekspresikan diri melalui karya seni dengan dapat menerapkan berbagai metode dapat menumbuhkan kreativitas serta meningkatkan kemampuan seni yang sudah ada pada diri anak. Namun dalam implementasinya, proses pembelajaran seni rupa hanya mengejar target kurikulum pada pembelajaran sehingga anak hanya diberikan tugas menggambar tanpa adanya arahan untuk berkreativitas. Hal ini disebabkan kurang kreatifnya guru dalam menerapkan berbagai macam metode dalam pembelajaran seni sehingga anak mengalami kesulitan untuk menumbuh kembangkan kreativitas. Dengan demikian anak akan terbatasi berkembangnya kreativitas dengan kurang memberikannya ruang gerak bagi anak sendiri.

Kegiatan menggambar sangat cocok dengan anak untuk mengekspresikan diri dan menumbuhkan kreativitas melalui kegiatan berkarya seni rupa dengan menggunakan metode collective painting. Metode collective painting merupakan metode yang diterapkan pada karya seni dengan ukuran cukup besar yang direncanakan terlebih dahulu dan kemudian diselesaikan oleh sekelompok anakanak. Sejalan dengan pendapat Garha (1980: 65) yang menyatakan bahwa metode collective painting adalah salah satu bentuk kerja kelompok dimana setiap anggota akan mendapatkan bagian khusus dari bidang yang akan mereka selesaikan. Sehingga metode collective painting merupakan salah satu metode yang bisa dimanfaatkan guna menumbuhkan kreativitas seni pada anak di desa Mayongkidul Jepara melalui kegiatan bermain sekaligus berseni.

Kreativitas merupakan kemampuan dalam mengungkapkan banyak ide secara mengalir yang dihasilkan dari melihat suatu masalah dari berbagai arah dan bersifat orisinalitas atau memiliki perbedaan dengan ide dari kebanyakan orang. Sesuai dengan pendapat Munandar (1985: 51) bahwa kreativitas adalah daya atau kemampuan untuk mencipta, cara berfikir dan bertindak atau membuat sesuatu yang baru dan nyata. Kreativitas memiliki ciri-ciri yakni kelancaran, fleksibilitas, orisinalitas, elaborasi, dan perincian. Seseorang dapat dikatakan akan semakin kreatif apabila mencakup ciri-ciri tersebut yang bersamaan dengan perkembangan afektifnya.

Pentingnya menumbuhkan kreativitas pada anak dimulai sejak usia sekolah dasar, dikatakan demikian karena setiap anak dilahirkan dengan potensi kreatif. Menurut Alifah dkk (2020: 4) menjelaskan bahwa ada beberapa faktor penghambat dalam menumbuhkembangkan kreativitas anak secara optimal diantaranya sebagai berikut:

1. Terlalu banyak larangan dapat menghambat pengalaman belajar. Hal ini akan menyebabkan kreativiats anak tidak akan bisa berkembang.

2. Memaksakan hanya satu cara yang mungkin sudah out of date.

3. Kurang menghargai karya anak, sehingga anak berhenti berkarya.

4. Kurang mengembangkan humor dalam proses pembelajaran. Humor tidak saja membuat relaks, tapi juga menyehatkan fisik dan mental.

5. Terlalu banyak komentar negatif atau kritik. 
6. Kurangnya pembiasaan membaca di rumah atau literasi.

7. Adanya pewarisan kebiasaan buruk yang ditularkan orang tua kepada anak.

Meskipun setiap anak memiliki potensi keatif alamiah di dalam dirinya, tapi potensi kreatif tersebut tidak akan optimal jika tidak digali dan diasah sejak dini.

Sementara itu, Prima dan Farida (2019: 1413) menyatakan bahwa indikator kreativitas anak meliputi pembentukan minat yang kuat dalam segala kegiatan seperti percaya diri dan mandiri, asyik dan turut dalam kegiatan, memperlihatkan keingintahuan, melakukan hal-hal baru dengan caranya sendiri (inisiatif) dan menggabungkan hal-hal atau ide-ide dengan cara-cara baru.

Penelitian ini memiliki kesamaan dengan penelitian yang dilakukan oleh Utami (2017), Sunarto (2018), Kasta (2019), dan Wibowo (2020), Penelitian yang dilakukan oleh Utami (2017) menunjukkan bahwa adanya keefektifan metode collective painting terhadap kreativitas siswa menggunakan uji pihak kanan yaitu One Sample t-Test dan diperoleh 9,298 > 2,052 (thitung >ttabel) dan nilai signifikasi yang diperoleh $0,00<0,05$.

Riset yang dilakukan oleh Sunarto (2018) menemukan bahwa pembelajaran seni memerlukan beberapa metode untuk dapat meningkatkan kreativitas siswa. Penggunaan berbagai model pembelajaran dapat menumbuhkan jiwa dan kreatifitas siswa. Senada dengan hasil penelitian Sunarto (2018, penelitian yang dilakukan oleh Kasta (2019) juga menemukan bahwa kreatifitas siswa dalam pembelajaran seni akan meningkat jika guru mau menggunakan berbagai macam metode pembelajaran yang menarik. Melalui dua siklus penelitian, didapatkan peningkatan kreatifitas siswa dalam pembelajaran seni. Siklus I menunjukkan kreatifitas siswa pada angka 47\%, sementara pada siklus II mengalami peningkatan menjadi $71 \%$.

Hasil penelitian Wibowo (2020) menunjukkan kreativitas seni pada anak usia dini dapat meningkat dengan pemilihan metode pembelajaran yang menarik. Melalui permainan warna cat air, anak-anak dapat mengekspresikan diri selama masa pandemi.

Anak di desa Mayongkidul Jepara terutama kelas III dan kelas $\mathrm{V}$ memiliki karakteristik yang dapat menghasilkan karya sempurna dan dapat mengekspresikan diri melalui karya tersebut. Hal ini dapat dibuktikan berdasarkan observasi dan wawancara yang dapat ditandai dengan beberapa karakteristik yaitu antusias, banyak akal, berfikiran terbuka, bersikap spontan, cakap, dinamis, giat dan rajin, serta idealis melalui kegiatan seni dengan menerapkan metode collective painting bertujuan untuk mengasah kepekaan rasa, kolaborasi \& fluensy, dan emosional.

Penjelasan tersebut melatarbelakangi peneliti untuk melaksanakan penelitian yang berjudul "Penerapan Metode Collective Painting untuk Menumbuhkan Kreativitas Seni pada Anak di Desa Mayongkidul Jepara" dengan tujuan untuk menganalisis pengaruh metode collective painting untuk menumbuhkan kreativitas seni pada anak di desa Mayongkidul Jepara.

\section{METODE PENELITIAN}

Penelitian ini dilaksanakan di desa Mayongkidul Jepara dengan enam anak sebagai subjek penelitian. Jenis penelitian ini berupa mixed methods (penelitian gabungan) dengan desain sekuensial eksploratori dimana hasil data kualitatif kemudian dianalisis secara beriringan dengan data kuantitatif melalui uji validitas dan uji reliabilitas. Adapun bagan desain metode penelitian sekuensial eksploratori dapat dilihat pada bagan 1 sebagai berikut:

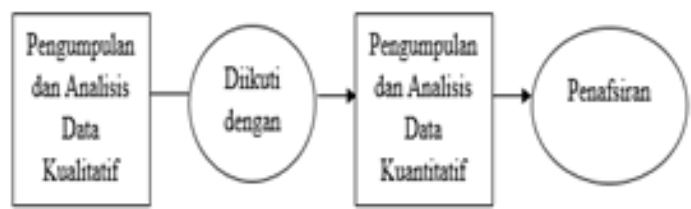

Bagan 1. Metode Penelitian Sekuensial Eksploratori

Teknik pengumpulan data pada penilitian ini didapat dari wawancara, observasi dan studi dokumentasi. Hasil data 
tersebut kemudian dianalisis dengan tahap pengumpulan data, penyajian data, transformasi data, korelasi data, konsolidasi data dan kesimpulan seperti yang dikemukakan oleh Onwuegbuzie dan Tiddlie (2003) dalam Creswell (2018: 333).

\section{HASIL DAN PEMBAHASAN}

Kegiatan menggambar pada anak memiliki tujuan tersembunyi yang sangat penting untuk menumbuhkan kreativits seni. Imajinasi dan fantasi mereka dalam mengekspresikan diri akan dapat diungkapkan dengan kegiatan yang positif bagi anak. Oleh karena itu kebebasan mengekspresikan diri dengan menerapkan metode collective painting dapat menumbuhkan kreativitas seni pada anak. Menurut Davis (2012: 259) kreativitas dapat diwujudkan dengan ciri-ciri aptitude (berpikir kreatif), ciri-ciri tersebut antara lain kelancaran, fleksibilitas, orisinalitas, dan elaborasi serta melalui ciri non-aptitude (afektif) meliputi rasa ingin tahu, imajinatif, tantangan, dan kemauan untuk mengambil risiko.

Sedangkan menurut Utami Munandar dalam Nelson (2016: 45-46) menjabarkan ciriciri kemampuan berpikir kreatif ialah: 1) Mencetuskan banyak gagasan, cara atau saran untuk melakukan berbagai hal, 2) Dapat melihat suatu masalah dari sudut pandang yang berbeda-beda, 3) Mampu memperkaya dan mengembangkan suatu gagasan atau produk, 4) menambahkan atau memperinci detil-detil dari suatu objek, gagasan atau situasi sehingga lebih menarik.

Sejalan dengan penelitian sebelumnya yang dilakukan oleh Utami pada (2017) dengan judul "Penerapan Metode Collective Painting Terhadap Kreativitas dan Hasil Belajar SBK Siswa Kelas III SDN Pesayangan 1 Kabupaten Tegal" menunjukkan bahwa: 1) Adanya perbedaan kreativitas siswa pada materi Gambar Imajinatif di kelas III SD yang menerapkan metode Collective Painting dengan yang tidak menerapkan dengan perolehan nilai thitung $=4,881$ yang didapat melalui uji hipotesis menggunakan uji $t$ dengan teknik Independent Sample t-Test pada program SPSS versi 21. 2) Adanya keefektifan metode Collective Painting terhadap kreativitas kelas eksperimen daripada kelas kontrol yang tidak menerapkan metode ini. Dari hasil uji hipotesis menggunakan uji pihak kanan yaitu One Sample t-Test pada program SPSS versi 21, diperoleh 9,298 > 2,052 (thitung $>$ ttabel) dan nilai signifikasi yang diperoleh $0,00<0,05$.

Adapun hasil analisis data kuantitatif disajikan dalam Tabel 1. sesuai berdasarkan analisis data kualitatif yang telah dipaparkan. Hasil data kuantitatif dapat dilihat pada gambar berikut.

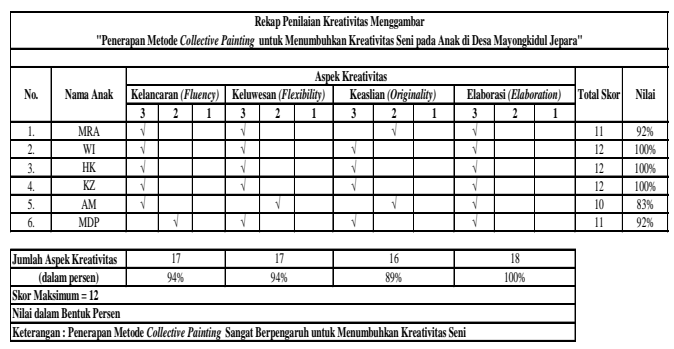

Gambar 1 Rekap Penilaian Kreativitas Seni melalui Metode Collective Painting

Berdasarkan hasil penelitian yang diperoleh dari wawancara, observasi dan kuesioner kepada anak di desa Mayongkidul Jepara menunjukan adanya aspek nilai dalam menumbuhkan kreativitas seni melalui penerapan metode collective painting. Pemaparan nilai-nilai tersebut disajikan dalam bentuk data kuantitatif dan data kualitatif. Adapun nilai-nilai kreativitas seni yang muncul melalui metode collective painting adalah sebagai berikut:

\section{Nilai Elaborasi}

Kegiatan seni melalui penerapan metode collective painting untuk menumbuhkan kreativitas seni memunculkan aspek elaborasi terhadap sekelompok anakanak. Nilai Elaborasi yang dimunculkan pada saat proses penerapan metode collective painting berlangsung sebesar $100 \%$ dengan kategori tinggi dalam penilaian kreativitas seni. Hal ini menunjukkan bahwa anak mampu menjelaskan pengembangan ide atau 
gagasannya secar detail meskipun gambarannya hanya berupa garis. Melalui penerapan metode collective painting anak mampu menjelaskan pengembangan ide atau gagasannya secara detail meskipun gambarannya hanya berupa garis. Sekelompok anak mampu menggambar objek sesuai tema dengan rapi untuk hasil karya seni. Pengembangan ide ini diutarakan anak bersama kelompoknya melalui cerita kemudian dibacakan di depan kelompok lain.

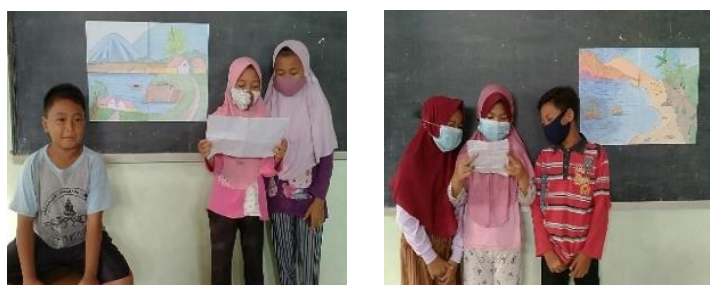

\section{Gambar 2. Bercerita Mengenai Hasil Karya Anak}

Nilai elaborasi pada penerapan metode collective painting tidak hanya dituangkan kepada hasil karya saja, namun anak juga mengeksplorasi kemampuannya melalui tulisan bercerita. Penulisan cerita dikerjakan secara berkelompok dengan tekun dan cermat dalam merangkai kata-kata. Anak juga merasa antusias bersemangat pada saat bercerita di depan kelompok lain.

\section{Nilai Kolaborasi}

Kegiatan seni dengan menerapkan metode collective painting memerlukan waktu yang relatif lama untuk menjadi sebuah karya seni utuh yang digunakan untuk menumbuhkan kreativitas seni. Supaya kegiatan seni dengan menerapkan metode collective painting cepat selesai dan menghasil sebuah karya perlu adanya kerja sama antara kelompok terutama anak di desa Mayongkidul Jepara. Menurut Soekanto (2006: 66) menyatakan bahwa kerjasama merupakan suatu usaha bersama antara orang perorang atau kelompok untuk mencapai tujuan tertentu. Sejalan dengan pendapat Listyani (2017) juga mengungkapkan bahwa kerjasama merupakan sikap penyelesaian dan pemecahan masalah yang di lakukan bersama-sama demi mencapai tujuan bersama.

Berdasarkan beberapa pendapat tersebut dapat disimpulkan bahwa kegiatan seni khususnya menggambar dengan menerapkan metode collective painting perlu adanya kerja sama atau kolaborasi antar kelompok supaya menghasilkan sebuah karya seni utuh nan indah secara aesthetic.
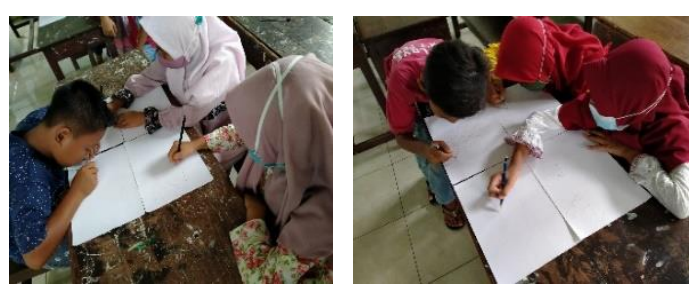

Gambar 3. Rancangan sket gambar

Nilai kolaborasi dan kelancaran (fluency) yang dimunculkan anak pada saat proses penerapan metode collective painting berlangsung sebesar94\% dengan kategori tinggi dalam penilaian kreativitas seni. Hal ini menandakan bahwa anak mampu menyelesaikan tugas menggambarnya secara bekerjasama dengan kelompok. Kerjasama tersebut dilaksanakan dengan lancar dan tepat sesuai arahan peneliti sehingga menghasilkan sebuah karya seni yang utuh.

Kegiatan seni dengan menerapkan metode collective painting diawali dengan berdiskusi antar kelompok guna menentukan tema yang akan digambar, selanjutnya setiap anggota kelompok membuat rancangan sket gambar pada kertas ukuran besar yang sudah dipetak-petak. Sket kemudian disusun dan dikoreksi kembali guna menyatukan gambar supaya terlihat utuh. Kegiatan seni selanjutnya adalah masing-masing anggota menyelesaikan tugas pemberian warna sesuai dengan hasil diskusi kelompok.
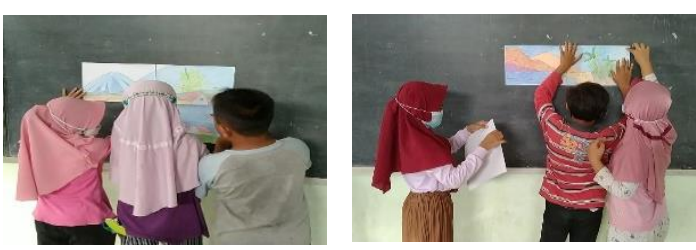

Gambar 4. Penyusunan gambar 
Pada tahap akhir, ketua dan anggota kelompok mengoreksi dan menyusun gambar supaya gambar yang dibuat oleh anggota kelompok menjadi satu kesatuan yang utuh baik goresan garis, bentuk, bidang, warna dan sebagainya.

Dari hasil penelitian tersebut dapat disimpulkan bahwa metode collective painting merupakan metode menggambar yang jenis panduan dan pembagian tugasnya perlu adanya kerja sama secara berkelompok atau kolaborasi. Pada saat anak-anak mengerjakan tugasnya, anak mengalami perkembangan sosial dan bersemangat dalam menyelesaikan tugasnya.

\section{Nilai Emosional}

Nilai emosional merupakan perasaan yang muncul dan hanyut dalam suasana menggambar dari dalam diri anak pada saat proses berlangsungnya kegiatan seni dengan menerapkan metode collective painting untuk menumbuhkan kreativitas seni. Kegiatan seni bisa dijadikan sebagai sarana permainan anakanak yaitu belajar sambil bermain. Sependapat dengan Fajrie (2016: 156) yang menyatakan bahwa kegiatan seni dimana belajar sambil bermain cocok untuk menumbuhkan kreativitas anak yang bisa disalurkan dengan mengekspresikan pribadi anak-anak untuk memunculkan nilai emosional anak.
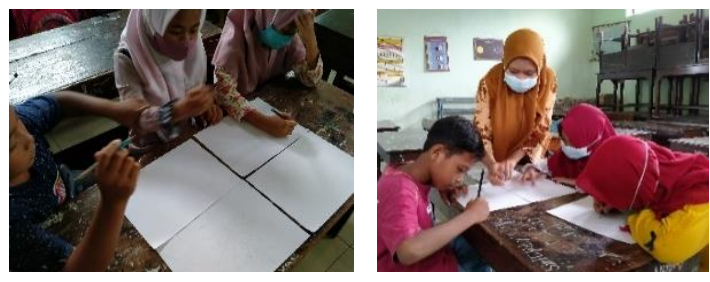

\section{Gambar 5. Penerapan Metode Collective Painting}

Hasil penelitian berdasarkan temuan lapangan menunjukkan bahwa menggambar dengan menerapkan metode collective painting menampakkan nilai emosional pada anak di desa Mayongkidul Jepara. Suasana tegang dan mencekam timbul pada saat anak berdiskusi mengutarakan ide dan pendapat mengenai tema yang digambar. Pada saat proses menggambar dengan menerapkan metode collective painting berlangsung, anak juga memperlihatkan emosionalnya berkelakuan sedih, gembira, senang, dan bersikap marah kepada temannya dikarenakan suka mengusik.

\section{SIMPULAN}

Metode collective painting merupakan salah satu metode yang diterapkan pada kegiatan berkarya seni dengan ukuran cukup besar yang direncanakan terlebih dahulu dan kemudian diselesaikan oleh sekelompok anakanak di desa Mayongkidul Jepara. Dalam pelaksanaan penerapan metode collective painting untuk menumbuhkan kreativitas seni tercermin aspek nilai elaborasi, nilai kolaborasi dan nilai emosional.

\section{DAFTAR PUSTAKA}

Alifah, F. A. (2020). Analisis Perkembangan Seni Kreativitas Siswa Kelas Rendah Muhammadiyah Pajangan 2 Yogyakarta. Journal of Islamic Primary Education, 3 (1), hal. 1-9.

Andini, M. D. (2019). Meningkatkan Kreativitas Peserta Didik dalam Melukis Melalui Teknik Finger Painting pada Pelajaran Seni Budaya. Jurnal EDUCARE, 17 (2), hal. 109-118.

Creswell, J. (2018). Mendesain dan Melaksanakan Mixed Methods Research Edisi ke-2. Yogyakarta: Pustaka Belajar.

Fajrie, N. (2016). Pengenalan Kegiatan Seni Rupa untuk Anak Tunanetra dalam Upaya Mengembangkan Kemampuan Sensitivitas. Jurnal Imajinasi, 10 (2), hal. 153-158.

Garha, O. d. (1980). Pendidikan Kesenian Seni Rupa. Jakarta: Rora Karya Offset.

Hasnawati dan Anggraini, D. (2016). Mozaik sebagai Sarana Pengembangan Kreativitas Anak dalam Pembelajaran 
Seni Rupa Menggunakan Metode

Pembinaan Kreativitas dan

Keterampilan. Jurnal PGSD, 9 (2) hal. 226-231.

Listiyani, P. H. (2017). Peningkatan Karakter Kerjasama Berbasis Layanan Bimbingan Klasikal dengan Pendekatan Metode Proyek. Yogyakarta: Universitas Sanata Dharma.

Munandar, U. (1985). Mengembangkan Bakat dan Kreativitas Anak Sekolah . Jakarta: PT. Gramedia.

Nelson Nelwandi, M. (2016). Kreativitas dan Motivasi dalam Pembelajaran Seni Lukis. Jurnal Ilmu Pengetahuan Sosial, 7 (1), hal. 42-58.

Onwuegbuzie, A. \&. (2003). A Framework for Analyzing Data in Mixed Methods Research. Dalam A. Tashakkori \& C. Tiddlie (Eds.), Handbook of Mixed Methods in Social \& Behavioral Research. Thousand Oaks, CA: Sage.

Prima, T. R. (2019). Peranan Kegiatan Finger Painting terhadap Perkembangan Seni Rupa dan Kreativitas Anak Usia Dini. Jurnal Pendidikan Tambusai, 3 (6), hal. 1411-1418.

S., J. Y. (2021). Optimalisasi Kreativitas Pembelajaran SBDP Menggunakan Bahan Alam Peserta Didik Kelas II
Candigaron 03 Tahun Ajaran 2020/2021. Journal of Education Research, 3 (2) hal. 40-52.

Sholiha, Nida. 2015. Penerapan Metode Pembelajaran Collective Painting dalam Mata Pelajaran Seni Budaya (Seni Rupa) (Analisis Deskriptif pada Siswa Kelas IX A SMP Negeri 1 Subang Tahun Pelajaran 2013/2014). Skripsi. UPI.

Soekanto, S. (2006). Sosiologi Suatu Pengantar. Jakarta: Raja Grapindo Persada.

Sumanto. (2006). Pengembangan Kreativitas Seni Rupa Anak Sekolah Dasar. Jakarta: Direktorat Jenderal Pendidikan Tinggi Direktorat Ketenagaan.

Kasta, Ahem. (2019). Peningkatan kreativitas seni anak melalui kolase dengan menggunakan daun pisang di TK Aisyiyah Talaok. JRTI, 3 (2) hal. 126131.

Wibowo, Devi Vionitta \& Suyadi. (2020). Kegiatan Kreativitas Seni Warna Anak Usia Dini Melalui Permainan Cat Air di Masa Pandemi. PAUD Lectura, 4 (1) hal. 74-87.

Sunarto. (2019). Pengembangan KreativitasInovatif Dalam Pendidikan Seni Melalui Pembelajaran Mukidi. Refleksi Edukatika, 8 (2) hal. 107-113. 